\title{
FLAXSEEDS NUTRITIONAL VALUE AND THE EFFECT OF ITS INCORPORATION IN SOME LOAF PROPERTIES WITH AND WITHOUT ADDITION OF TRANSGLUTAMINASE
}

\author{
Nawal. H. Sebo \\ Brwa. M. Said \\ Halala. W. Alikhan \\ Food Technology Department, Collage of Agriculture, Salahaddln University, \\ Iraq\Erbil \\ Email: nawal.sebo@su.edu.krd
}

\begin{abstract}
The aim of this study was to determine the major nutrients in local flaxseeds, the amino acids content, the fatty acids content of extracted oil, and to investigate the effects of 5\%seeds flour replacement and addition of microbial transglutaminase on some properties of dough and loaf bread. Results showed that these seeds contained 4.93, 22.28, 36.03, 31.03, 18.03, 3.63and 1.08\% (w/w) of moisture, protein, fat, total carbohydrates, crude fiber, ash and reducing sugars respectively with $1.83 \mathrm{mg} \backslash 100 \mathrm{gm}$ sample of Vitamin C. Results of amino acids analysis indicated aspartic acid, glutamic acid, arginine as non -essential and tryptophan and phenylalanine as essential amino acids to be the main components of seeds protein, they represent 4.522, 3.486, 1.88 and 2.414, $0.695 \mathrm{gm} / 100 \mathrm{gm}$ sample respectively. The analysis of fatty acids content, showed twenty nine fatty acids. Unsaturated fatty acids spatially $\alpha$-linolenic and oleic acids, were predominant, they comprise 24.94 and $22.79 \mathrm{~g} / 100 \mathrm{~g}$ of the total FA respectively, while palmitic acid was the major saturated fatty acid found in seeds and comprised $13.60 \%$ of total lipid. The minerals, calcium, manganese, potassium and iron, were present in high concentrations. Results indicated that the replacement of wheat flour by $5 \%$ ground flaxseed decreased wet gluten, tolerance index, loaf specific volume and increased dough water absorption, stability and fermentation gassing power. Sensory evaluation showed that the incorporation of these seeds flour had a slightly unfavorable effect on bread sensory properties but ensured satisfactory consumer acceptability. Addition 2 units $\backslash \mathrm{g}$ protein of microbial transglutaminase caused increasing in wet gluten, gassing power of fermented dough, loaf specific volume and all sensory attributes.

Key Words: Flaxseed; Nutritional Value; Microbial Transglutaminase; Composed Loaf
\end{abstract}

Received:14/4/2019, Accepted:10/10/2019

\section{INTRODUCTION}

Flax (Linum usitatissimum L.) is an annual herbaceous blue flowering plant that belongs to the Lineaceae family. The plant produces small flat and oval with a pointed tip seeds varying from golden yellow to reddish brown color. In the past it was used for medical purposes and as energy source. Currently, it is cultivated in more than 50 countries to represent an important food, oil and fiber crop (Rubilar $e t$ al., 2010).

Many studies have shown the significant nutritional characteristics of the flax seed and their hulls. It is recommended for consumption because it is a cheap and 
rich source of oil, protein, minerals, insoluble and soluble dietary fibers, as well as is one of the richest vegetable sources of the essential fatty acid $\alpha$ - linolenic acid that should be consumed in a normal diet. They might also be considered as a source of high-value biologically active compounds such as tocopherols, antioxidants and phytochemicals (Morris, 2001; Hosseinian et al., 2006; Singh et al . 2011; Herchi et al., $2014 \mathrm{a}$ and b and Panaite et al., 2017).

All these nutritional properties provide health benefits and have positive effects preventing and/or therapeutic of consumers from some diseases (Rodriguez-Leyva, et al., 2010; Lowcock et al., 2013, Wahba and Al-Zahrany, 2013 and Sharma, 2016), which considered flaxseed to be an attractive functional food or source of functional ingredients and promising for its utilization in different foodstuffs, as consumers are increasingly interested in functional foods due to the growing awareness of the link between diet and health (Oomah, 2001 and Goyal et al.,2014).

Flaxseed incorporation in food products has been the focus of many studies, which includes bread, muffins, batter, cookies, cereal bars and others (Mentes, ${ }_{3}$." et al., 2008; Shearer and Davis, 2005; Khouryieh and Aramouni, 2012 and 2013).

Bread is usually prepared from wheat flour, water, and yeast that after kneading, the mixture forms elastic dough. It is the one of the most consumed food around the world. Sanchez et al. (2015) stated that its consumption does not supply enough fibre, omega-3 fatty acid and antioxidant for human diet. To increase these compounds, bread enriched with flax seeds flour could be a good alternative to produce composite bread. However, addition of flax seeds flour may have un desirable effects on the rheological properties of dough and maintaining quality and competitiveness of the products. Therefore, the search for new ingredients in the food industry has grown in recent years. Among these ingredients, there is the enzyme microbial transglutaminase (MTGase) which is the best choice as compared with chemical compounds because it is generally recognized as safe (GRAS) and does not remain active after baking (Seravalli et al. 2011).

Transglutaminase (protein-glutamine $\gamma$-glutamyltransferase, EC: 2.3.2.13) is an enzyme that catalyzes the acyl transfer reactions, allows to create intra and/or intermolecular cross-links through the formation of covalent isopeptide bonds $(\mathcal{E}-\gamma$ Glu-Lys) resulting in the polymerization of food proteins (Kuraishi et al., 2001).

Many studies on the applications of MTGase in diversity of food proteins are available. They confirm that the enzyme improves some properties of foods like nutritional value, flavour, appearance, serum holding capacity, emulsifying properties, viscosity, solubility, heat stability, gel firmness, texture, shelf life and reduced allergenicity (kuraishi et al., 2001; Kieliszek and Misiewicz, 2014).

The purpose of the present work was to determine the proximate compositions, amino acids, fatty acids and mineral profile of locally produced flaxseeds and to provide information on how partial replacement of wheat flour by these seeds at a 5 $\%$ level and MTGase addition affects the dough properties, performance and overall acceptance of composite bread.

\section{MATERIALS AND METHODS}

Chemicals and raw materials: 
All chemical used were of analytical grade and purchased locally.

Flax seeds (FS) were provided from Erbil agriculture research Centre, cleaned, packed in polypropylene bags and stored at $5{ }^{\circ} \mathrm{C}$ until further use and grounded using a grinder with cooling system before analysis.

Commercial bread wheat flour (WF) $80 \%$ extraction was passed through sieve size 9xx $(150 \mu)$ produced by BETWATA Milling Co.

Commercial dry yeast and salt: were purchased from local market from Erbil.

Microbial transglutaminase (MTGase) was supplied by Ajinomoto Co., Inc., Tokyo, Japan.

Chemical analysis was achieved as follow:

Sample of flax seeds was analyzed for chemical composition (moisture, protein, fat, ash and crude fiber) using the Anonymous procedures (2000). Crude protein content $(\mathrm{N} \times 6.25)$ of the samples was estimated by the micro Kjeldahl method. Crude fat was determined by extracting a known weight of powdered seeds with diethyl ether, using a Soxhlet apparatus. Ash content was determined by incineration at $600{ }^{\circ} \mathrm{C}$ for $3 \mathrm{~h}$. to obtain carbon free white ashes. Total carbohydrates were calculated by difference. Also the moisture and protein content of wheat flour were measured using the methods which mentioned above.

Amino acids were determined using LC-MS HPLC analyzer (RMIT UniversityMelbourne, Victoria, Australia- School of Health and Biomedical Sciences CollegeDepartment of Medical Sciences). An Agilent 1200 LC-system coupled to an Agilent 6410 Electro spray Ionisation-Triple Quadrupole-MS was used for quantification experiments. Agilent Technologies 6890 gas chromatography using helium as the carrier gas and a flame ionization detector.

According to Pearson and Cox (1976) the fatty acids within the lipid extracts were derivative to fatty acid methyl esters (FAME) using 14\% boron trifluoridemethanol FAMEs then analyzed by gas chromatography-mass spectrometry (GCMS) chromatography (RMIT University- Melbourne, Victoria, Australia- School of Health and Biomedical Sciences College- Department of Medical Sciences).

For Minerals determination, the obtained ashes were dissolved in hydrochloric acid, filtered and analyzed in lab of Kurdistan Institution for Strategic Studies / Sulaymaniyah city. Sodium and potassium were analyzed by flame atomic absorption spectrophotometry using A A Analyst 700 (Perkin Elmer).While calcium, magnesium, iron, copper ,zinc and selenium were measured by inductive couple plasma optical emission spectrophotometry(ICP OES,Optima2100 DV ).

Reducing sugars in seeds sample were determined by the DNS colorimetric methods with glucose as the standard and the absorbance values were read at 540 mm (Miller, 1959).

Vitamin $\mathrm{C}$ content in flax seed was also analyzed using the spectrophotometric method according to the method described by (Pearson and Cox 1976).

Wet gluten content of flour blends was determined by method as described in (Anonymous, 2000). Water absorption, development time, stability and Tolerance index of dough prepared from each of the flour blends were determined by Farinograph equipped with a 300 g-stanless steel bowl (Brabender Farinograph Germany) according to (Anonymous, 2000). 
A pressure meter method according to Anonymous (2000) was used to determine the gas production by baker`s yeast and WF before and after addition of FS and MTGase.

Modified straight dough baking method according to Anonymous (2000) was followed for WF and their blends (WF + 5\% grounded FS and WF + 5\% grounded FS +MTGase).

Sensory evaluation of bread samples were carried out by 10 panelists on a 9 point hedonic scale for different parameters such as crumb, crust colour, odour, taste, texture and overall acceptability as described by Ihekoronye and Ngoddy (1985). The 10 untrained panellists were staff of Food Technology Department of Salahaddin University shared together in evaluating the laboratory made breads.

\section{RESULTS AND DISCUSSION}

The proximate compositions of flax seeds are given in Table 1.

Table (1): Proximal compositions of flax seeds (\%).

\begin{tabular}{|c|c|}
\hline Component & Content \\
\hline Moisture & $4.93 \pm 0.015$ \\
\hline Protein & $22.28 \pm 0.4$ \\
\hline Lipids & $36.03 \pm 0.3$ \\
\hline Carbohydrates + Epaminondas et al. fiber & $31.03 \pm 1.38$ \\
\hline Crude Fiber & $18.03 \pm 0.05$ \\
\hline Ash & $3.63 \pm 0.02$ \\
\hline Reducing sugars & $1.08 \pm 0.17$ \\
\hline Vitamin C (mg\100gm) & $1.83 \pm 0.23$ \\
\hline
\end{tabular}

Results are expressed as $(\mathrm{x} \pm \mathrm{d})$, being $\mathrm{x}$ the average and $\mathrm{d}$, the standard deviation $(\mathrm{n}=3)$. Values are mean \pm standard deviation of triplicate determinations

The sample showed adequate levels of nutrients, confirming the possibility of their use as dietary products. Seeds with low moisture content level could be stored for a long time since higher moisture content could cause decomposition of fatty acids by microbial action and pro-oxidants. Also, the data revealed that the flax seeds were rich in fat, protein and dietary fiber making it an ideal energy source material and its high content of dietary fiber may prevent or reduce the risk of various diseases (Du et al. 2010). Results of previous studies achieved by Daun et al.(2003); Morris, (2007); Bozan and Temelli ( 2008) and Khouryieh and Aramouni (2013) showed that the range of flax seeds chemical compositions were 6-8\% moisture, 33.6- 41\% lipid, 17.9-21\% total protein, $29-38.1 \%$ total carbohydrates, 2.4- 3.9\% ash, 24.5-28.2\% dietary fiber and 0.9-2 \% soluble carbohydrates . Flax seeds contain small quantities of vitamin $\mathrm{C}$ (total ascorbic acid) as shown in Table 1, it was more than that recorded by Morris (2007); Daun et al. (2003) and Rubilar et al., (2010). The variation may be due to the diversity of variety, maturity, growing region, growing environmental conditions and method of analysis. Results concerning amino acids content of protein in flax seeds are summarized in Table 2. 
Results indicate that non-essential amino acids were present in different amounts. Among these amino acids glutamic acid and aspartic acid were the major and present in a high level, also arginine is present in appropriate level which has a good nutritive value especially for children and is a precursor of nitric oxide, which increase HDL-cholesterol concentration in serum(Abuelgassim and Al-showayman, 2012). On the other hand, tryptophan and phenylalanine showed the highest concentration among all detected essential amino acids, but the sample had the lowest content of methionine and lysine. Also flax seeds contain traces of uncommon amino acids including $\beta$-alanine, $\gamma$ - amino-butyric acid, 4-hydroxy-proline, putrescine, taurine and ornithine which are the intermediate products remains during protein metabolism.

Table (2): Amino acids profile of flax seeds.

\begin{tabular}{|c|c|c|c|c|c|}
\hline \multicolumn{2}{|c|}{$\begin{array}{l}\text { Non-essential amino acids } \\
(\mathrm{g} / 100 \mathrm{~g} \text { seeds })\end{array}$} & \multicolumn{2}{|c|}{$\begin{array}{l}\text { Essential amino acids } \\
\quad(\mathrm{g} / 100 \mathrm{~g} \text { seeds })\end{array}$} & \multicolumn{2}{|c|}{$\begin{array}{l}\text { Other amino acids } \\
\text { (g/100g seeds })\end{array}$} \\
\hline Alanine & $0.562 \pm 0.029$ & Isoleucine & $0.321 \pm 0.029$ & B-Alanine & $0.035 \pm 0.001$ \\
\hline Arginine & $1.88 \pm 0.1700$ & Leucine & $0.191 \pm 0.006$ & $\begin{array}{c}\gamma-\mathrm{NH} 2- \\
\text { butyricacid }\end{array}$ & $0.120 \pm 0.030$ \\
\hline $\begin{array}{l}\text { Aspartic } \\
\text { acid }\end{array}$ & $4.522 \pm 0.305$ & Lysine & $0.175 \pm 0.010$ & 4-H-Proline & $0.044 \pm 0.005$ \\
\hline Asparagine & $1.368 \pm 0.011$ & Methionine & $0.110 \pm 0.003$ & Putrescine & $0.018 \pm 0.002$ \\
\hline Cystine & $0.014 \pm 0.002$ & Phenylalanine & $0.695 \pm 0.037$ & Taurine & $0.025 \pm 0.002$ \\
\hline $\begin{array}{l}\text { Glutamic } \\
\text { acid }\end{array}$ & $3.486 \pm 0.178$ & Threonine & $0.612 \pm 0.021$ & Ornithine & $0.040 \pm 0.003$ \\
\hline Glutamine & $0.316 \pm 0.039$ & Tryptophan & $2.414 \pm 0.053$ & - & - \\
\hline Glycine & $0.412 \pm 0.041$ & Valine & $0.496 \pm 0.021$ & - & - \\
\hline Histidine & $0.490 \pm 0.047$ & - & - & - & - \\
\hline Proline & $0.685 \pm 0.047$ & - & - & - & - \\
\hline Serine & $0.234 \pm 0.016$ & - & - & - & - \\
\hline Tyrosine & $0.579 \pm 0.041$ & - & - & - & - \\
\hline
\end{tabular}

Results are expressed as $(x \pm d)$, being $x$ the average and $d$, the standard deviation $(n=3)$.

Chung et al. (2005) revealed that flax protein is relatively rich in arginine, aspartic and glutamic acids and the limiting amino acids are lysine, methionine and cysteine. Results obtained by Kaur et al. (2017) showed that proteins of different flaxseed cultivars were rich in glutamic acid, alanine with tryphtophan, valine and lysine being the main essential amino acids.

Results of fatty acids (FA) analysis of flax seeds oil which presented in Figure 1, showed that flax seeds were characterized by a high percentage of UFA, which form about $72.21 \%$ of the total FAs, with their main components being $\alpha$ - linolenic acid (ALA, C18:3 n-3; 24.94g/100g of the total FA) and oleic acid (C18:1 n-9; $22.79 \mathrm{~g} / 100 \mathrm{~g}$ of the total FA). Fatty acids were in the following order of abundance: $\alpha$-linolenic acid $(\mathrm{C} 18: 3)>$ oleic acid $(\mathrm{C} 18: 1)>$ palmitic acid $(\mathrm{C} 16: 0)>$ linoleic acid $(\mathrm{C} 18: 2)>$ stearic acid (C18:0). Thus, the incorporation of flax seed oil into the diet would be very favorable due to the high content of UFAs spatially essential fatty acids which have been recognized to provide numerous health benefits and seeds with high unsaturated FA, a fatty acids which helps the body to absorb fat-soluble 
vitamins Omega-3, also act to protect the heart by lowering blood pressure, bad cholesterol, and inflammation.(Riemersma, 2001; Bowen and Clandinin 2005; Gammone, et al.,2019). Results were in agreement with findings reported in earlier studies conducted by Bozan and Temelli (2008) and Bernacchia et al. (2014). They stated that major FAs were $\alpha$-linolenic and oleic acids but lower content of $\alpha$ linolenic acid was found in the present study. On the other hand, the investigation achieved by Kakilashvili, et al. (2014) showed that flax seeds oil contained $31.3 \%$ linoleic and $40.2 \%$ linolenic acids beside palmitic and stearic acids in less quantitates.

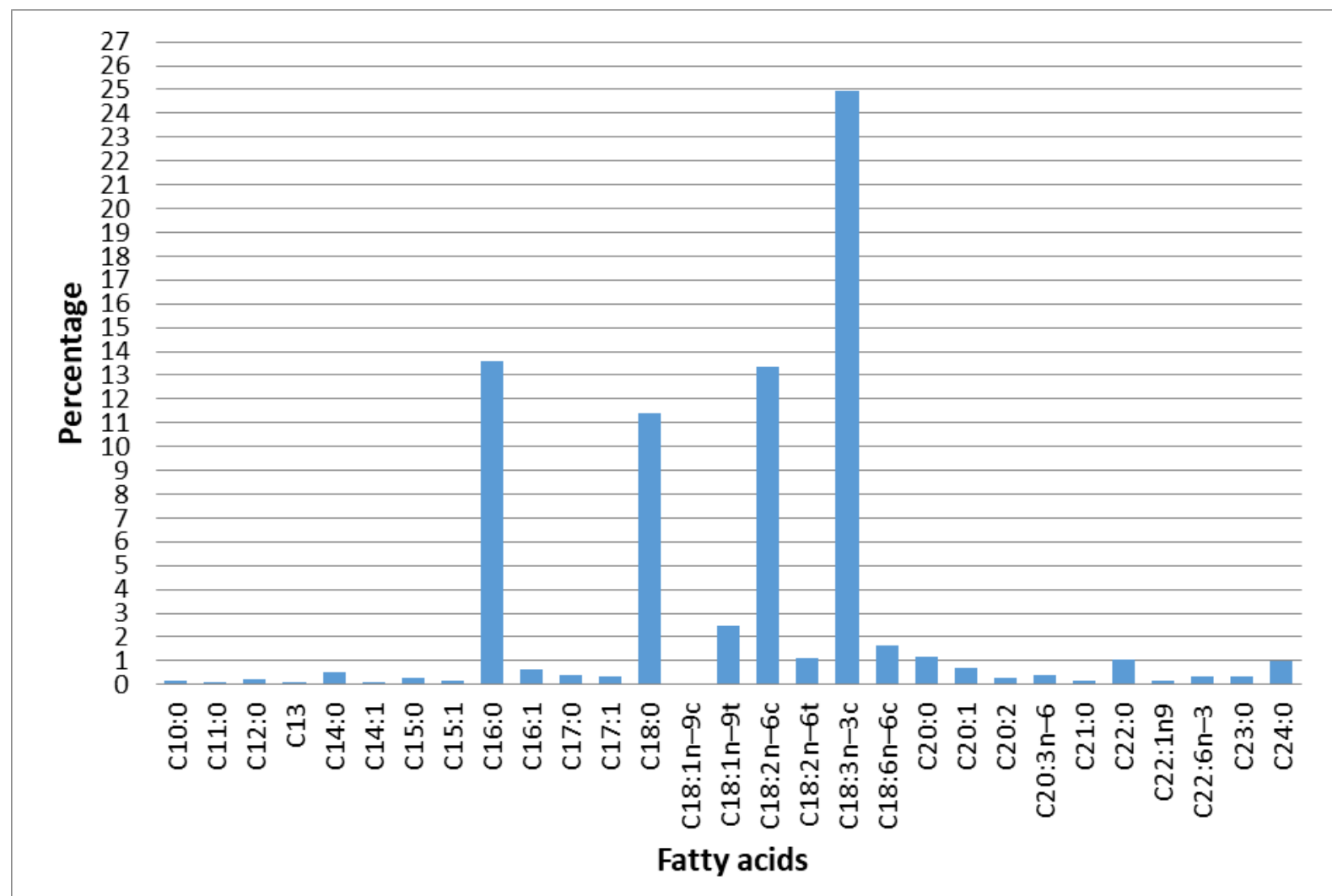

Figure (1): Fatty acidscontent of flax seeds oil (Data are expressed as $\mathrm{g} / 100 \mathrm{~g}$ of total fatty acid).

The variations among the concentrations of fatty acids may attributed to many factors such as cultivation region of the plant, geographic location of the crop, differences in the environment, climate changes, availabilities of nutrient, year of cultivation and soil conditions (Oomah, 2001). Also FAs such as pentadecanoic, heptadecanoic, arachidonic, docosanoic and docosahexaenoic acids were found in this study.

Regarding the determination of some minerals content in flax seeds which includes $\mathrm{Ca}, \mathrm{Mg}, \mathrm{K}, \mathrm{Na}, \mathrm{Fe}, \mathrm{Zn}, \mathrm{Cu}$ and $\mathrm{Se}$, the results showed that $\mathrm{Ca}$ and $\mathrm{Mg}$ form the highest proportion Table 3.The results were differ than that indicated by Hussain et al, (2008) and Morris (2007).They reported that Mg was the most abundant mineral in these seeds. Since flax seeds contain a high level of $\mathrm{Ca}$, it is useful for bone health and to be used as milk substitute for people who suffer from allergy 
against lactose. The low $\mathrm{Na}$ and the high $\mathrm{K}$ content in flax seeds of the present study was also illustrated by Morris (2007) and Kaur, et al. (2017). They conferred that these seeds are important for people with high blood pressure. Other minerals that are found in flax seeds include Zinc, Iron, Copper and Selenium. It is clear that flaxseed could be significant in contributing to the daily dietary intake of important elements.

Table (3): Mineral content of flax seeds.

\begin{tabular}{|c|c|}
\hline Element & Content $(\mathrm{mg} / 100 \mathrm{gm})$ \\
\hline $\mathrm{Ca}$ & $550.86 \pm 2.86$ \\
\hline $\mathrm{Mg}$ & $123.01 \pm 0.07$ \\
\hline $\mathrm{K}$ & $80.47 \pm 0.39$ \\
\hline $\mathrm{Na}$ & $4.70 \pm 0.10$ \\
\hline $\mathrm{Fe}$ & $19.65 \pm 1.73$ \\
\hline $\mathrm{Zn}$ & $3.11 \pm 0.11$ \\
\hline $\mathrm{Cu}$ & $1.46 \pm 0.08$ \\
\hline $\mathrm{Se}$ & $0.14 \pm 0.01$ \\
\hline
\end{tabular}

Results are expressed as $(x \pm d)$, being $x$ the average and $d$, the standard deviation $(n=3)$.

Table 4 shows that the addition of flax seeds flour to wheat flour caused decreasing of moisture and increasing of ash, protein and lipid content of their blend due to low moisture and high of other components in flax seeds. A similar result for these chemical characteristics was also reported by (Marpalle et al., 2014 ).

Table (4): Effect of flaxseed flour and MTGase addition on the compositions percentage of wheat flour blend.

\begin{tabular}{|c|c|c|c|c|c|}
\hline Samples & Moisture & Ash & Protein & Lipid & Wet gluten \\
\hline Flax Seeds & $4.93 \pm 0.015$ & $3.63 \pm 0.02$ & $22.28 \pm 0.4$ & $36.03 \pm 0.3$ & - \\
\hline Wheat flour & $\begin{array}{c}10.91 \\
\pm 0.14\end{array}$ & $0.67 \pm 0.01$ & $11.94 \pm 0.1$ & $0.97 \pm 25$ & $29.9 \pm 0.55$ \\
\hline $\begin{array}{c}\text { Wheat flour+ } \\
5 \% \text { Flaxseed }\end{array}$ & $9.80 \pm 0.26$ & $0.82 \pm 0.03$ & $12.38 \pm 0.2$ & $2.42 \pm 0.4$ & $18.28 \pm 0.13$ \\
\hline $\begin{array}{c}\text { Wheat flour+ } \\
5 \% \text { Flaxseed } \\
+ \text { MTGase }\end{array}$ & - & - & - & - & $22.5 \pm 1.27$ \\
\hline
\end{tabular}

Results are expressed as $(\mathrm{x} \pm \mathrm{d})$, being $\mathrm{x}$ the average and $\mathrm{d}$, the standard deviation $(\mathrm{n}=3)$.

Concerning to Gluten protein which forms continuous network that gives dough its viscoelastic properties is an important consideration in baking Carson and Edwards (2009), flaxseed supplementation in level 5\% blend showed negative effects on wet gluten due to the dilution of gluten and the incorporation of non-gluten protein.

Addition of $2 \mathrm{U} / \mathrm{g}$ protein of MTGase to the blend showed an increase in wet gluten value and this might be due to the interactions of the proteins subunits, Basman et al. (2003) and Koh and $\mathrm{Ng}$ (2009) reported that the amount of wet gluten 
increased with the addition of MTGase as a results of the intra and inter crosslinkages of proteins polypeptide chains via new isopeptide bonds introduced by the transglutaminase and led to formation of a more stable protein network , which reduced the solubility of gluten proteins and increased of the high molecular weight polymers.

Table 5 illustrated the Farinograph characteristics before and after addition of 5\% flaxseed flour and MTGase to wheat flour which had a direct effect on the quality of the end product. It shows an increasing in water absorption to values between 63.5 and $63.8 \%$ after addition of MTGase and flax seeds as compared to control sample. Many studies revealed that water absorption increased with the increase of flaxseed addition level in wheat flour dough and they stated that this is mainly due to the high water binding capacity of dietary fibers and gums present in flaxseed (Koca and Anil 2007; Marpalle et al., 2014; Xu, et al. 2014 and Pourabedin et al., 2017).

Table (5): Effect of flaxseed flour and MTGase addition on Farinograph parameters and loaf specific volume.

\begin{tabular}{|c|c|c|c|c|c|}
\hline Samples & $\begin{array}{c}\text { Absorption } \\
\text { of water on } \\
14 \% \mathrm{mb}\end{array}$ & $\begin{array}{c}\text { Development } \\
\text { time (min) }\end{array}$ & $\begin{array}{c}\text { Stability } \\
(\mathrm{min})\end{array}$ & $\begin{array}{c}\text { Tolerance } \\
\text { index } \\
\text { FU }\end{array}$ & $\begin{array}{c}\text { Specific } \\
\text { volume } \\
(\mathrm{ml} / \mathrm{g})\end{array}$ \\
\hline Wheat flour & 62.9 & 1.9 & 2.9 & 56 & $3.81 \pm 0.14$ \\
\hline $\begin{array}{c}\text { Wheat flour+ } \\
5 \% \text { Flaxseed }\end{array}$ & 63.8 & 8.3 & 13.2 & 23 & $2.85 \pm 0.03$ \\
\hline $\begin{array}{c}\text { Wheat flour+ } \\
5 \% \text { Flaxseed } \\
\text { +MTGase }\end{array}$ & 63.5 & 1.9 & 9.5 & 21 & $3.58 \pm 0.02$ \\
\hline
\end{tabular}

A longer dough development time, increased in dough stability time and decreased mixing tolerance index were noticed after addition of flax seeds flour as revealed Table 5. This may be resulted from high protein content, and to the nature of nongluten protein of flax seeds flour. Similar results were found by (Roozegar et al., 2015).

As shown in Table 5 addition of flaxseed flour caused the decreasing of loaf specific volume. This might be due to the dilution of wheat gluten which caused the disruption of the gluten network during fermentation and loss of some of the carbon dioxide formed during this process. Result were disagreed with those observed by Mentes et al., (2008) and Meral and Donga (2013), while addition of MTGase increased this value Table5. The improving role of enzyme associated to the crosslinking and interactions of different protein subunits of wheat flour with flax seeds proteins which improved the quality of bread making were also reported by (Basman et al., 2003 and Koh and NG 2009).

The data in Table 6 illustrated that the gassing power measured as $\mathrm{mm} \mathrm{Hg}$ during five hours fermentation at $35^{\circ} \mathrm{C}$ was higher for wheat flour with $5 \%$ flaxseed flour (172 $\mathrm{mm} \mathrm{Hg}$ at the end of five hour's) compared to control flour $(130 \mathrm{~mm}$ 
$\mathrm{Hg}$ ). The higher gas production may be due to the fermentable soluble fibers in the flaxseed.

Table (6): Fermentation gassing power ( $\mathrm{mmHg}$ ) averages of wheat flour and their blends at different times.

\begin{tabular}{|l|l|l|l|l|l|}
\hline Samples & $1 \mathrm{hr}$ & $2 \mathrm{hr}$ & $3 \mathrm{hr}$ & $4 \mathrm{hr}$ & $5 \mathrm{hr}$ \\
\hline Wheat flour & $22 \pm 0.05$ & $38 \pm 0.01$ & $60 \pm 0.02$ & $100 \pm 0.01$ & $130 \pm 0.02$ \\
\hline $\begin{array}{l}\text { Wheat flour+ } \\
5 \% \text { Flaxseed }\end{array}$ & $22 \pm 0.01$ & $46 \pm 0.02$ & $94 \pm 0.02$ & $140 \pm 0.01$ & $172 \pm 0.03$ \\
\hline $\begin{array}{l}\text { Wheat flour+ } \\
\text { 5\% Flaxseed } \\
\text { +MTGase }\end{array}$ & $24 \pm 0.01$ & $74 \pm 0.01$ & $110 \pm 0.04$ & $146 \pm 0.02$ & $184 \pm 0.05$ \\
\hline
\end{tabular}

Results are expressed as $(\mathrm{x} \pm \mathrm{d})$, being $\mathrm{x}$ the average and $\mathrm{d}$, the standard deviation $(\mathrm{n}=3)$.

Concerning the role of MTGase on flour blends attitudes during fermentation, the data in Table 6 showed positive effect in increasing the production of $\mathrm{CO}_{2}$. Similar results were obtained by Ilia (2011) who stated that the positive role of MTGase on gas production during fermentation of wheat flours and their blends with different varieties of barley is not well understood and mentioned that the interpretation of these findings could be caused by the positive effect of MTGase in modifying the enzymatic system ( $ß$ - amylase of flours and the enzymes of the yeast) hence making them more efficient in producing available sugars and as well as converting these sugars to $\mathrm{CO}_{2}$ or could be related to using of crud MTGase that contributed in this phenomena.

The effect of flaxseed flour and microbial transglutaminase on the sensory evaluation of the loaf is summarized in Table 6 .

Table (7): Sensory evaluation.

\begin{tabular}{|c|c|c|c|c|c|}
\hline Samples & Appearance & Colour & Texture & Flavour & $\begin{array}{c}\text { Overall } \\
\text { Acceptability }\end{array}$ \\
\hline $\begin{array}{c}\text { Wheat flour } \\
\begin{array}{c}\text { Wheat flour + 5\% } \\
\text { Flaxseed }\end{array}\end{array}$ & 9.42 & 9.28 & 9.14 & 8.57 & 8.71 \\
\hline $\begin{array}{c}\text { Wheat flour + 5\% } \\
\text { Flaxseed +MTGase }\end{array}$ & 9.57 & 9.57 & 8.57 & 8.21 & 8.57 \\
\hline
\end{tabular}

Results showed that loaf made with 5\% flaxseed flour had gained lowest scores, while the 5\% flaxseed flour with 2units MTGase /gm. protein loaf had got highest scores among most sensory attributes.

Mercier et al. (2014) reported that cereal products fortification with flaxseed supplements generally had a negative influence on the sensory characteristics such as flavour, texture, and colour. 
Regarding to effects of MTGase, several pupillages had mentioned to improve the sensory properties such as texture, mouth feel, flavour, appearance and conformation of food products by treating with this enzyme (Kuraishi et al., 2001 and Yokoyama et al.2004).

\section{CONCLUSION}

The results revealed that flaxseeds are rich in protein, fat and fibers. These could therefore serves as economic and substitution source of proteins in the diet. Aspartic acid, glutamic acid, arginine as non-essential amino acids and tryptophan and phenylalanine as essential amino acids were the most abundant amino acids. $\alpha$ linolenic, oleic, palmitic acids were predominant fatty acids. The level of mineral and trace elements in the flaxseeds were relatively high. The addition of 5\% flax seeds flour resulted in increasing of water absorption, amount of $\mathrm{Co}_{2}$ during fermentation, dough development time, stability time of dough and decrease in wet gluten and specific volume. By supplementation wheat flour with flax seeds, bread had a less organoleptic acceptance. Addition of microbial transglutaminase produces bread with more acceptable rheological and organoleptic characteristics.

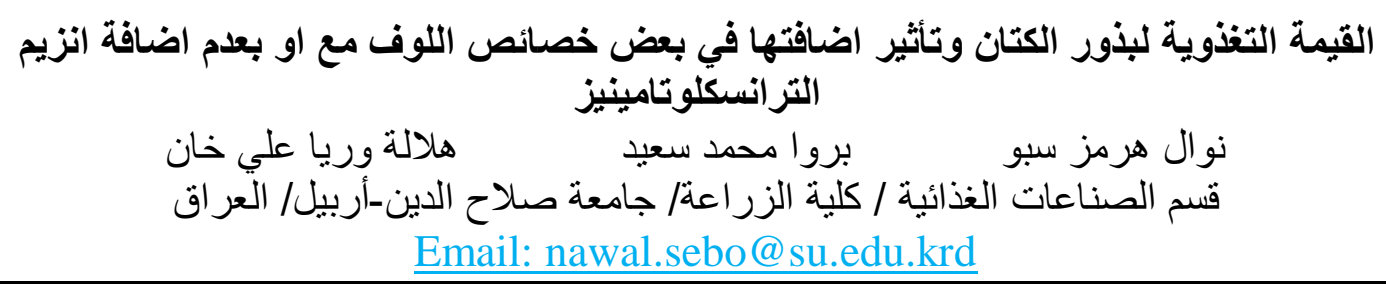




\section{REFERENCES}

Anonymous. (2000). Approved Methods of the American Association of Cereal Chemists, $10^{\text {th }}$ Ed. Anonymous International: St. Paul, MN.

Abuelgassim A.O. and S. I. Al-showayman (2012). The effect of pumpkin (Cucurbita pepo L) seeds and L-arginine supplementation on serum lipid concentrations in atherogenic rats. African Journal of Traditional, Complementary and Alternative medicines, 9 (1):131-137.

Anonymous (Association of Official Analytical Chemists) (2000). Official Methods of Analysis, $17^{\text {th }} \mathrm{Ed}$, Washington.

Basman, A., H. Köksel and P. K. W. Ng (2003).Utilization of transglutaminase to increase the level of barley and soy flour incorporation in wheat flour breads. Journal of Food Science, 68:2453-2460.

Bernacchia, R., R. Preti and G. Vinci (2014).Chemical composition and health benefits of flaxseed. Austin Journal of Nutrition and Food Science, 2 (8), id 1045.

Bowen, R. A. R. and M. T. Clandinin (2005).Maternal dietary 22:6n_3 is more effective than 18:3n_3 in increasing content in phospholipids of cells from neonatal rat brain. British Journal of Nutrition, 93:601-611.

Bozan, B. and F. Temelli (2008).Chemical composition and oxidative stability of flax, safflower and poppy seed and seed oils. Bioresource Technology,99(14):6354-6359.

Carson, G. R. and N.M. Edwards (2009).Criteria of Wheat Flour Quality: 99-108 in: Wheat Chemistry and Technology, $4^{\text {th }}$ Ed.K.Khan and P. R. Shewry, eds. Anonymous International: St.Paul,MN.

Chung, M., B. L. Lei and E. Chan (2005).Isolation and structural characterization of the major protein fraction from normal flax seed. (Linum Usitatissium L.).Food Chemistry, 90(1-2):271-279.

Daun J.K., J.V .Barthet, T.L. Chornick and S. Duguid (2003).Structure, composition, and variety development of flaxseed.In: Cunnane SC and Thompson LU (eds) Flaxseed in Human Nutrition. Champaign, IL: AOCS Press: $1-40$.

Du, H., A. D.L. van der, H.C. Boshuizen, N.G. Forouhi and N.J .Wareham (2010). Dietary fiber and subsequent changes in body weight and waist circumference in European men and women. American Journal of Clinical Nutrition, 91(2):329-336.

Gammone, M. A., G. Riccioni, G. Parrinello and N. D’Orazio (2019).Omega-3 Polyunsaturated Fatty Acids: Benefits and Endpoints in Sport.Nutrients,11(1):1-50.

Goyal, A., V.Sharma, N. Upadhyay, S. Gill and M. Sihag (2014). Flax and flaxseed oil: an ancient medicine \& modern functional food. Journal of Food Science and Technology.51 (9):1633-1653.

Herchi, W., D. Arráez-Román, H. Trabelsi, I. Bouali, S. Boukhchina, H. Kallel and A. Fernández-Gutierrez (2014a). Phenolic compounds in flaxseed: A review of their properties and analytical methods. An overview of the last decade. Journal of Oleo Science, 63(1):7-14. 
Herchi, W., A. D. Al Hujaili, , F. Sakouhi, K. Sebei, , H. Trabelsi, H. Kallel and S. Boukhchina (2014b). Flaxseed hull Chemical composition and antioxidant activity during development. Journal of Oleo Science, 63(7):681-689.

Hosseinian F.S., A. D. Muir, N. D. Westcott and E.S. Krol (2006).Antioxidant capacity of flaxseed lignans in two model systems. Journal of the American Oil Chemists Society, 83:835-840.

Hussain, S, F. Muhammad, A. M. B. Sadiq and M. S. Ahmad (2008). Chemical compositions and functional properties of flaxseed flour. Journal of Agriculture, 24(4):649-653.

Ihekoronye, A.I. and P.O. Ngoddy (1985). Integrated Food Science and Technology for the Tropics. Macmillan Publishers Ltd., London, ISBN: 9780333388839: 109.

Ilia, E. B. (2011). Role of Transglutaminase in Wheat-Barley Flour BlendsBaking Quality. MSc. Thesis, Food Technology Department, College of Agriculture, Salahaddin University.

Kakilashvili, B., D. Zurabashvili, D. G. Turabelidze, L. Shanidze and G. K. Parulava (2014).The fatty acid composition of ordinary flax seed oil (Linum usitatissimum L.) cultivated in Georgia and its byological activity. Georgian medical news (1512-0112), (227):86-88.

Kaur, M., R. Kaur and B. S. Gill (2017). Mineral and amino acid contents of different flaxseed cultivars in relation to its selected functional properties. Food Measure, 11:500-511.

Khouryieh, H. and F. Aramouni (2012). Physical and sensory characteristics of cookies prepared with flaxseed flour. Journal of the Science of Food and Agriculture 92(11):2366-2372.

Khouryieh, H. and F. Aramouni (2013). Effect of flaxseed flour incorporation on the physicalproperties and consumer acceptability of cereal bars. Food Science and Technology International 19(6):550-556.

Kieliszek, M. and A. Misiewicz (2014). Microbial transglutaminase and its application in the food industry. A review. Folia Microbiol (2014) 59:241-250.

Koh, B. K., and P. W. K. Ng (2009). Effects of ferulic acid and transglutaminase on hard wheat flour dough and bread. Cereal Chemistry. 86 (1):18-22.

Koca, A. F. and M. Anil (2007). Effect of flaxseed and wheat flour blends on dough rheology and bread quality. Journal of Food Science and Agriculture, 87(6): 1172-1175.

Kuraishi, C., K. Yamazaki and J. Susa (2001). Transglutaminase: Its utilization in the food industry. Food Reviews International, 17:221- 246.

Lowcock, E. C., M. Cotterchio and B. A. Boucher (2013). Consumption of flaxseed, a rich source of lignans, is associated with reduced breast cancer risk. Cancer Causes and Control, 24(4):813-816.

Marpalle, P., K. Sonawane, and S. S. Arya (2014). Effect of flaxseed flour addition on physicochemical and sensory properties of functional bread. LWT - Food Science and Technology, 58:614-619. 
Mentes, O.", E. Bakkalbassi and R. Ercan (2008). Effect of the use of ground flaxseed on quality and chemical composition of bread. Food Science and Technology International 14(4):299-306.

Meral, R. and I.S. Dogan (2013). Quality and antioxidant activity of bread fortified with flaxseed. Italian Journal of Food Science 25(1):51-56.

Mercier, S., S. Villeneuve, C. Moresoli, M. Mondor, B. Marcos, and K. A. Power (2014). Flaxseed-Enriched Cereal-Based Products:A Review of the Impact of Processing Conditions. Comprehensive Reviews in Food Science and Food Safety, 14(4):400-411.

Miller, G. L. (1959).Use of Dinitrosalicylic acid reagent for determination of reducing sugar. Analytical Chemistry, 31:426-428.

Morris, D. H. (2001). Essential nutrients and other functional compounds in flaxseed. Nutrition Today 36:159-162.

Morris, D. H. (2007) Flax-a Health and Nutrition Primer, $4^{\text {th }}$ ED. Available from: www.flaxcouncil.ca

Oomah, B. D. (2001). Flaxseed as a functional food source. Journal of the Science of Food and Agriculture, 81:889- 894.

Panaite, T., M. Ropota, R. Turcu, M. Olteanu, A. R. Corbu and V. Nour (2017). Flaxseeds: nutritional potential and bioactive compounds. Bulletin UASVM Food Science and Technology, 74(2):66-73.

Pearson, D. and H. E. Cox (1976). The Chemical Analysis of Foods. $7^{\text {th }}$.Ed . Edinburgh; New York : Churchill Livingstone.

Pourabedin, M., A. Aarabi and S. Rahbaran (2017). Effect of flaxseed flour on rheological properties, staling and total phenol of Iranian toast. Journal of Cereal Science, 76: 173-178.

Riemersma, R. A. (2001).The demise of n-6 to n-3 fatty acid ratio? A dossier. European Journal of Lipid Science and Technology, 103(6):372-373.

Rodriguez-Leyva, D., C. M. Dupasquier, R. McCullough and G.N. Pierce (2010). The omega-3 fatty acid alpha linolenic acid within flaxseed provides beneficial cardiovascular effects. Canadian Journal of Cardiology, 26(9):489-496.

Roozegar, M. H., M. Shahedi, J. Keramet, N. Hamdami and S. Roshanak( 2015). Effect of coated and uncoated ground flaxseed addition on rheological, physical and sensory properties of Taftoon bread. Journal of Food Science and Technology, 52: 5102-5110.

Rubilar, M., C. Gutiérrez, M. Verdugo, C. Shene and J. Sineiro (2010). Flaxseed as a source of functional ingredients. Journal of Soil Science and Plant Nutrition, $10(3): 373-377$.

Sanchez-Garcia, M., F. Álvaro, J. A. Peremarti, A. Martín-Sánchez and C. Royo (2015). Changes in bread-making quality attributes of bread wheat varieties cultivated in Spain during the 20th century. European Journal of Agronomy 63:79-88.

Seravallia, E. A. G., A. M. Igutia, I. Santanaa and F. F. Filho (2011). Effects of application of transglutaminase in wheat proteins during the production of Bread. Procedia Food Science 1:935 - 942. 
Sharma, D. (2016). Impact of Supplementation with Flax seed powder and flax seed oil on the Lipid levels of Patients with Dyslipidemia. International Journal of Nutritional Science and Food Technology, 2 (3):89-94.

Shearer A.E.H. and C.G.A. Davis (2005). Physicochemical properties of freshly baked and stored whole-wheat muffins with and without flaxseed meal. Journal of Food Quality 28(2):137-153.

Singh, K., D. Mridula, J. Rehal and P. Barnwal (2011) Flaxseed: a potential source of food, feed and fiber. Critical Reviews in Food Science and Nutrition, 51(3):210-222.

Wahba, H. M. A., and M. S. H. Al-Zahrany (2013). Effect of feeding on diets supplemented by some vegetable oils on blood lipids and bone mineral content in osteoporotic rats. Life Science Journal, 10(1):1458-1465.

Xu, Y., C.A. Hall and F.A. Manthey (2014). Effect of flaxseed flour on rheological properties of wheat flour dough and on bread characteristics. Journal of Food Research International,3 : 83-91.

Yokoyama, K., N. Nio and Y. Kikuchi (2004). Properties and applications of microbial transglutaminase. Applied Microbiology and Biotechnology, 64:447-454. 